\title{
Analisis Komparatif Kinerja Reksa Dana Konvensional dan Syariah pada Periode Krisis dan Non Krisis
}

\section{Ananda Oktadino Anggriawan Firman ${ }^{1}$ Gerianta Wirawan Yasa ${ }^{2}$}

\author{
${ }^{1,2}$ Fakultas Ekonomi dan Bisnis Universitas Udayana (Unud), Bali, Indonesia \\ e-mail: aoktadino@gmail.com
}

\begin{abstract}
ABSTRAK
Tujuan penelitian ini adalah untuk mengetahui perbedaan kinerja reksa dana konvensional dan syariah pada periode krisis dan non krisis. Untuk mengukur kinerja reksa dana, metode yang digunakan adalah metode Sharpe. Sampel pada penelitian ini dipilih menggunakan metode purposive sampling. Sampel yang diambil pada penelitian ini yaitu sebanyak 8 sampel reksa dana yang terdiri dari 4 reksa dana konvensional dan 4 reksa dana syariah pada tahun 2008 dan 38 sampel reksa dana yang terdiri dari 19 reksa dana konvensional dan 19 reksa dana syariah pada tahun 2016. Teknik analisis yang digunakan adalah Independent Sample T-test. Hasil analisis menunjukkan bahwa kinerja reksa dana syariah dan konvensional pada tahun 2008 tidak terdapat perbedaan. Pada tahun 2016, hasil pengujian Independent T-Test menunjukkan bahwa kinerja reksa dana syariah lebih baik dibandingkan dengan kinerja reksa dana konvensional.
\end{abstract}

Kata kunci: Kinerja, reksa dana, konvensional, syariah.

\begin{abstract}
The purpose of this study was to determine the differences in the performance of conventional and syariah mutual funds in the crisis and non-crisis periods. To measure the performance of mutual funds, the method used is the Sharpe method. The sample in this study was selected using a purposive sampling method. The samples taken in this study is as many as 8 samples of mutual funds consisting of 4 conventional mutual funds and 4 syariah mutual funds in 2008 and 38 samples of mutual funds consisting of 19 conventional mutual funds and 19 syariah mutual funds in 2016. Techniques The analysis used was the Independent Sample T-test. Results of the analysis show that the performance of syariah and conventional mutual funds in 2008 did not differ. In 2016, the results of the Independent T-Test showed that there were differences in performance between syariah and conventional mutual funds.
\end{abstract}

Keywords: Performance, mutual funds, conventional, syariah.

\section{PENDAHULUAN}

Sharpe (2015) mengatakan bahwa investasi merupakan pengorbanan pada saat ini untuk memperoleh keuntungan pada masa yang akan datang. Dari pernyataan Sharpe ini dapat disimpulkan bahwa investasi adalah sejumlah dana yang digunakan dengan harapan dapat memberikan keuntungan tertentu di masa yang 
akan datang. Harta yang dimiliki oleh seseorang, harus diputar dalam perekonomian kepada hal yang produktif agar menghasilkan return bagi pemiliknya dan bermanfaat bagi orang lain (IAEI, 2013)

Dalam berinvestasi, para investor dihadapkan pada dua faktor yang mempengaruhi investasi yaitu risiko dan return. Pengembalian (return) yang merupakan imbalan yang diperoleh dari investasi. Return dapat dibagi menjadi dua, yaitu pengembalian yang telah terjadi (actual return) yang dihitung berdasarkan data historis dan pengembalian yang diharapkan (expected return) akan diperoleh investor di masa depan. Investasi sebenarnya tidak bisa lepas dari risiko, karena investasi dan risiko merupakan dua bagian yang tidak dapat dipisahkan. Investasi dengan risiko yang rendah biasanya hanya memberikan return yang relatif rendah juga, sedangkan jika risiko yang ditawarkan tinggi maka return yang didapat juga relatif tinggi. Menurut (Lawn, Westmoreland, Kiely, Lennon, \& Vernino, 2003) terdapat tiga jenis investor yang juga dikaitkan dengan preferensinya, yaitu: 1) Investor yang menyukai risiko (risk seeker), 2) Investor yang netral terhadap risiko (risk neutral) dan 3) Investor yang tidak menyukai risiko (risk averter).

Indonesia saat ini memiliki perkembangan dunia investasi yang semakin pesat. Banyak masyarakat yang tertarik dan masuk ke bursa untuk melakukan kegiatan investasi. Hal ini membuktikan bahwa dunia investasi semakin berkembang yang membuat para pengelola dana ramai-ramai menciptakan berbagai produk investasi yang ditawarkan kepada masyarakat. Investasi sendiri memiliki beranekaragam alternatif investasi berupa investasi pada realasset dan 
financial asset. Real asset sendiri merupakan investasi berupa aset nyata dan berwujud seperti tanah, bangunan, emas dan kekayaan lainnya. Financial asset berinvestasi pada aset keuangan yang berupa surat-surat berharga pada pasar uang maupun pasar modal.

Pasar modal merupakan salah satu instrumen investasi penting dalam perekonomian. Dunia industri dan perusahaan memanfaatkan pasar modal ini sebagai media untuk menyerap investasi dan memperkuat struktur modal (Otoritas Jasa Keuangan, 2016). Pasar modal juga memiliki peran yang sangat penting bagi perekonomian suatu negara karena pasar modal sendiri memiliki dua fungsi. Fungsi pertama adalah sebagai sarana perusahaan untuk mendapatkan dana dari masyarakat pemodal (investor). Dana yang diperoleh dari pasar modal dapat digunakan pengembangan usaha, ekspansi, penambahan modal kerja dan lain-lain. Fungsi keduanya adalah sebagai sarana bagi masyarakat untuk berinvestasi pada instrumen keuangan seperti saham, obligasi, reksa dana dan lain-lain. Dengan dimikian, masyarakat dapat menempatkan dana yang dimilikinya sesuai dengan karateristik keuntungan dan risiko masing-masing instrumen (Herlianto, 2010). Keuntungan berinvestasi di pasar modal yaitu memberikan tambahan pendapatan yang dapat berupa capital gain maupun dividen bagi investor. Menurut UU. No.8 Tahun 1995 Pasal 1 ayat 13 pasar modal merupakan suatu tempat untuk kegiatan yang berkenaan dengan penawaran umum dan perdagangan efek, perusahaan publik yang berkaitan dengan efek yang diterbitkannya, serta lembaga dan profesi yang berkaitan dengan efek. Secara umum, pasar modal diartikan sebagai suatu pasar yang memperjualbelikan produk berupa dana yang bersifat abstrak. Dalam 
bentuk aslinya, produk yang diperjualbelikan di pasar modal berupa lembar suratsurat berharga di bursa efek (Tandelilin, 2001).

Berdasarkan definisi menurut UU Pasar Modal No.8 Tahun 1995 Pasal 1 Ayat 27 , reksa dana adalah wadah yang dipergunakan untuk menghimpun dana dari masyarakat pemodal untuk selanjutnya diinvestasikan dalam portofolio efek oleh manajer investasi yang telah mendapat izin dari Bapepam. Reksa dana merupakan instrumen yang baik bagi investor pemula karena reksa dana hanya membutuhkan dana yang sedikit dan waktu yang tidak banyak.Dengan menambahkan dana milik kolektif itu kedalam berbagai objek investasi (portofolio) maka risiko investasi dapat dikurangi. Reksa dana juga diharapkan dapat meningkatkan peran pemodal lokal untuk berinvestasi di pasar modal Indonesia.

Perusahaan yang menerbitkan reksa dana pertama kali didirikan oleh pemerintah yaitu PT. Danareksa pada tahun 1976. Pada saat PT. Danareksa itu dibentuk, perusahaan tersebut menerbitkan reksadana yang disebut dengan sertifikat Danareksa. Tahun 1997 Ekonomi Islam di Indonesia mulai bangkit. Bangkitnya ekonomi Islam ini menjadi fenomena yang menarik dan menggembirakan terutama bagi penduduk Indonesia yang mayoritasnya adalah beragama Islam, sehingga pengembangan produk pasar modal yang berbasis syariah perlu ditingkatkan. PT. Danareksa kemudian memperkenalkan kembali reksa dana, namun kali ini reksa dana tersebut berbasis syariah yang disebut dengan reksa dana syariah. (Fatwa Dewa Syariah Nasional (DSN) MUI Nomor 
20/DSN MUI/IX/2001 tentang pedoman pelaksanaan investasi untuk reksadana syariah).

Dalam reksa dana sendiri terdapat jenis-jenis reksa dana yang berbeda. Setiap jenis reksa dana tersebut memiliki kinerja yang berbeda-beda. Kinerja reksa dana dapat dilihat dari Nilai Aktiva Bersih setiap jenis reksa dana. Menurut Hermawan \& Wiagustini (2016) besarnya NAB dari suatu reksadana merupakan alat ukur untuk menilai kinerja reksadana. Penurunan nilai aktiva bersih (NAB) akan berdampak pada penurunan kinerja reksadana juga.Grafik Nilai Aktiva Bersih setiap jenis reksa dana dapat dilihat pada gambar 1.

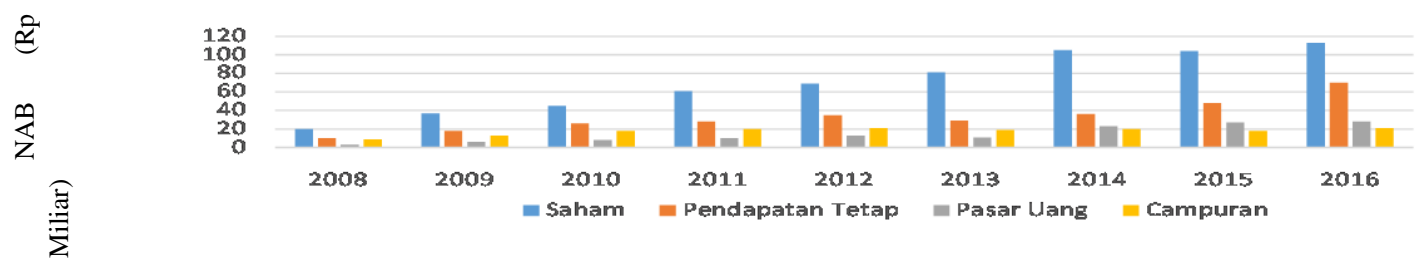

Gambar 1. Nilai Aktiva Bersih Jenis Reksa Dana tahun 2008 - 2016 Sumber: ojk.go.id, 2017

Reksa dana syariah sebagai alternatif investasi yang ditawarkan bagi pemodal muslim, dimana mayoritas masyarakat Indonesia adalah muslim. Keberadaan reksa dana syariah tidak bisa dipandang sebelah mata karena pada tahun-tahun berikutnyajumlah produk reksadana Syariah mengalami perkembangan dan pertumbuhanyang signifikan (Syariah \& Indonesia, n.d.). Perbedaan jumlah reksa dana konvensional dan reksa dana syariah yang terdapat di Indonesia dapat dilihat dari gambar2. 


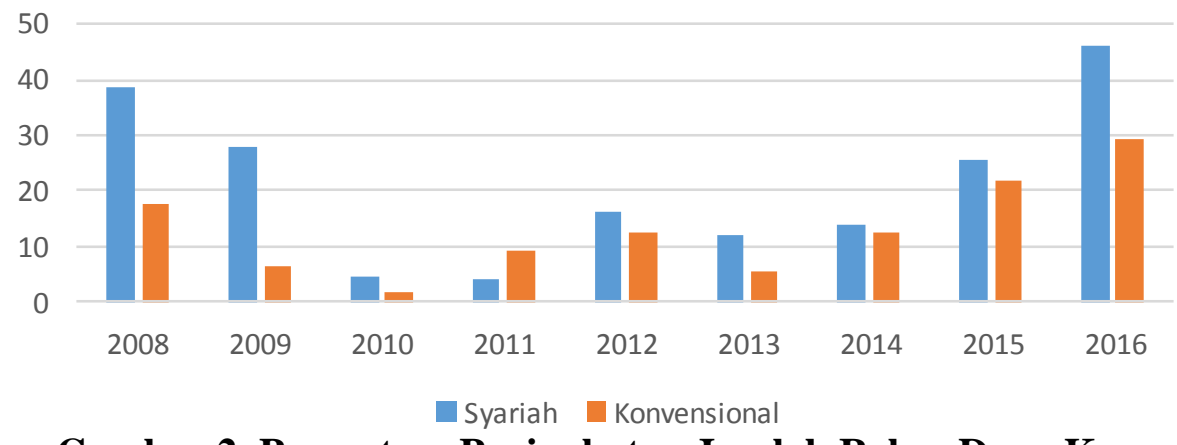

Gambar 2. Persentase Peningkatan Jumlah Reksa Dana Konvensional dan Syariah tahun 2008 - 2016

Sumber: ojk.go.id, 2017

Banyak investor yang bukan muslim berinvestasi juga pada reksa dana syariah. Hal ini disebabkan karena investor yang bukan muslim menganggap reksa dana syariah lebih menguntungkan dibandingkan dengan reksa dana konvensional. Investor akan selalu berinvestasi pada sesuatu yang menguntungkan. Gambar 2menunjukkan persentase peningkatan jumlah reksa dana syariah dengan reksa dana konvensional.

Krisis ekonomi yang terjadi pada tahun 2008 yang terjadi di Amerika juga sangat berpengaruh dalam keadaan ekonomi yang terjadi di Asia khususnya Indonesia. Perekonomian dalam suatu negara juga berpengaruh dengan pasar modal yang ada di negara tersebut. Akibat terjadinya krisis ekonomi pada tahun 2008, reksa dana konvensional hanya mengalami peningkatan jumlah sebesar $18,79 \%$ dan mengalami penurunan NAB sebesar $19,70 \%$ dari tahun sebelumnya. Peningkatan jumlah dan penurunan NAB reksa dana konvensional sangat berbeda dengan reksa dana syariah. Reksa dana syariah mengalami peningkatan jumlah sebesar $38,46 \%$ dan penurunan NAB sebesar $17,62 \%$ dari tahun sebelumnya. Peningkatan jumlah dan penurunan NAB menunjukkan bahwa reksa dana syariah 
memiliki peningkatan jumlah reksa dana yang lebih besar dan penurunan NAB yang lebih kecil jika dibandingkan dengan reksa dana konvensional.

Pada tahun 2016 Indonesia mengalami pertumbuhan ekonomi yang baik. Tahun 2016 juga menjadi rekor tertinggi dalam sejarah pasar modal Indonesia dimana dana yang berhasil dihimpun sepanjang tahun tersebut sebesar Rp 674,39 Triliun. Hal tersebut disampaikan oleh divisi komunikasi PT. Bursa Efek Indonesia yaitu Yulianto Aji Sadono dalamwawancara yang dilakukan oleh Tempo pada tahun 2016. Bank Indonesia juga menerbitkan laporan pertumbuhan ekonomi Indonesia, dimana pertumbuhan ekonomi Indonesia pada tahun 2016 tercatat sebesar 5,02\% membaik dibandingkan tahun 2015 sebesar 4,88\%. Selain laporan dari Bank Indonesia, hal lain yang dapat dilihat yaitu peningkatan jumlah dan peningkatan NAB dari reksa dana. Reksa dana konvensional pada tahun 2016, jumlahnya meningkat sebesar 29,16\% dan mengalami peningkatan NAB sebesar 23,93\% dari tahun sebelumnya. Peningkatan yang dialami reksa dana konvensional lebih kecil jika dibandingkan dengan reksa dana syariah. Reksa dana syariah pada tahun 2016 mengalami peningkatan jumlah sebesar 46,24\% dan peningkatan NAB sebesar $35,35 \%$ dari tahun sebelumnya. Hal ini sangat berbanding terbalik saat terjadi krisis ekonomi global.

Dalam pesatnya perkembangan instrumen reksa dana konvensional maupun syariah, terdapat masalah yang akan dihadapi oleh para investor. Masalah yang mungkin akan dihadapi oleh investor adalah bagaimana memilih reksa dana yang tepat sesuai dengan keadaan ekonomi saat ini. Apakah lebih baik memilih syariah atau memilih konvensional di keadaan ekonomi yang sedang baik maupun buruk. 
Oleh karena itu, pengukuran kinerja antara reksa dana syariah dan konvensional dalam kondisi ekonomi krisis maupun non krisis sangat penting untuk dilakukan.

Pada dasarnya masih banyak terjadi perdebatan di kalangan para ahli tentang reksa dana mana yang memiliki kinerja lebih baik antara reksa dana syariah dengan reksa dana konvensional. Ini dapat dilihat dari beberapa penelitian terdahulu seperti penelitian Syahna (2009) melakukan penelitian berupa membandingkan reksa dana berbasis syariah dan berbasis konvensional dan mendapat hasil bahwa kinerja produk reksa dana berbasis syariah lebih baik daripada kinerja reksa dana berbasis konvensional. Hasil penelitian ini sesuai dengan penelitian yang dilakukan oleh (Lestari, 2016) dan Djaddang \& Susilawati (2016). Selain itu hasil penelitian yang dilakukan oleh Hayat \& Kraeussl (2011) menunjukkan bahwa kinerja reksa dana konvensional lebih baik dari reksa dana syariah. Hasil penelitian ini sesuai dengan penelitian yang dilakukan oleh Merdad, Hassan, \& Alhenawi (2010). Pada penelitian yang dilakukan oleh Putra \& Fauzie (2014) menunjukkan bahwa tidak dapat pesrbedaan yang signifikan antara reksa dana syariah dan konvensional. Hasil penelitian ini sesuai dengan penelitian yang dilakukan Syafrida, Aminah, \& Waluyo (2014), Buana (2016), Mansor \& Ishaq Bhatti (2011). Sedangkan pada hasil penelitian yang dilakukan oleh Margaretha \& Lyberisa (2014) menunjukkan bahwa secara umum, kinerja kepercayaan unit konvensional dan syariah memiliki perbedaan yang signifikan terhadap return dan tingkat risiko dasar, namun berdasarkan timing pasar tidak ada perbedaan.

Untuk meningkatkan return dalam berinvestasi, investor sebaiknya melakukan investasi menyebar pada berbagai instrumen di pasar modal. Salah 
satu caranya dengan membeli reksa dana saham karena reksa dana saham memberikan return yang cukup tinggi dan paling banyak diminat oleh investor. Selain itu kondisi pasar modal sangat dipengaruhi oleh keadaan ekonomi. Apabila ekonomi mengalami kondisi yang baik, maka pasar modal cenderung mengalami keadaan bullish. Sebaliknya, apabila ekonomi mengalami kondisi yang buruk, maka pasar modal cenderung mengalami kondisi bearish.

Saat terjadi krisis ekonomi global yang terjadi pada tahun 2008 dan menyebabkan domino effect terhadap lembaga keuangan negara-negara maju dan merambat ke belahan Asia termasuk Indonesia sendiri. Reksadana sebagai salah satu instrumen investasi baik itu reksadana syariah maupun konvensional dalam pasar modal juga ikut terpengaruh atas krisis global yang terjadi. Pada saat periode krisis global yang terjadi, antara reksa dana syariah dan konvensional memiliki hasil kinerja yang berbeda.Reksa dana syariah pada saat periode krisis pada tahun 2008 mengalami peningkatan jumlah reksa dana dari tahun sebelumnya sebesar $38,46 \%$ dan mengalami penurunan NAB hanya sebesar 17,62\%. Peningkatan jumlah reksa dana dan penurunan NAB yang dialami reksa dana syariah lebih baik jika dibandingkan dengan reksa dana konvensional. Reksa dana konvensional mengalami peningkatan jumlah reksa dana hanya $18,79 \%$ dan penurunan NAB sebesar $19,70 \%$ dari tahun sebelumnya. Selain itu terdapat penelitian yang dilakukan oleh Hussein (2005) menunjukkan bahwa kinerja indeks Islam lebih baik daripada indeks tandingannya dalam keseluruhan periode. Dari penjelasan dan hasil penelitian tersebut, dapat disimpulkan bahwa:

$\mathrm{H}_{1}$ : Reksa dana saham syariah memiliki kinerja yang lebih baik dari reksa dana saham konvensional pada periode krisis. 
Pada tahun 2016, Indonesia mengalami kondisi ekonomi yang cukup baik. Hal ini dapat ditunjukkan dengan peningkatan jumlah dan NAB reksa danapada tahun 2016. Jumlah reksa dana syariah meningkat 46,24\% dari tahun sebelumnya. NAB reksa dana syariah juga meningkat sebesar 35,35\% dari tahun sebelumnya. Peningkatan jumlah reksa dana dan NAB reksa dana syariah lebih besar dibandingkan reksa dana konvensional. Reksa dana konvensional hanya mengalami peningkatan jumlah sebesar $29,16 \%$ dan peningkatan NAB hanya sebesar 23,93\%. Penelitian yang dilakukan oleh Putra \& Fauzie (2014) menyatakan bahwa tingkat pengembalian reksa dana syariah lebih baik dari pada reksa dana konvensional. Selain hal tersebut, reksa dana syariah juga memiliki risiko yang lebih kecil dibandingkan reksa dana konvensional. Dengan demikian dapat disimpulkan bahwa:

$\mathrm{H}_{2}$ : Reksa dana saham syariah memiliki kinerja yang lebih baik dari reksa dana saham konvensional pada periode non krisis.

\section{METODE PENELITIAN}

Pada penelitian ini, reksa dana yang diamati kinerjanya adalah reksa dana saham konvensional dan reksa dana saham syariah. Selanjutnya dilakukan analisis statistik uji beda dua rata-rata dengan program SPSS 20 sehingga dapat diketahui apakah terdapat perbedaan yang signifikan antara returndan risiko darireksa dana saham konvensional dan reksa dana saham syariah.

Obyek penelitian ini adalah reksa dana syariah dan reksa dana konvensional yang kategori portofolionya terdapat $80 \%$ saham.Berdasarkan pada pokok 
masalah yang telah dirumuskan serta hipotesis yang diajukan, variabel yang digunakan dalam penelitian ini adalah kinerja reksa dana yang dihitung menggunakan metodeSharpe.Sebelum menghitung metode Sharpe, terlebih dahulu menghitung tingkat pengembalian investasi (Return) reksa dana. Tingkat pengembalian investasi atau return reksa dana dapat dihitung dengan rumus sebagai berikut:

$R_{i}=\frac{\left[N A B_{t}-N A B_{t-1}\right]}{N A B_{t-1}}$

$\mathrm{R}_{\mathrm{i}} \quad=$ Tingkat pengembalian investasi

$\mathrm{NAB}_{\mathrm{t}}=$ Nilai aktiva bersih periode $\mathrm{t}$

$\mathrm{NAB}_{\mathrm{t}-1}=$ Nilai aktiva bersih periode $\mathrm{t}-1$

Deviasi standar reksa dana

$$
\sigma_{\bar{i}}=\sqrt{\Sigma \frac{\left[R_{i}-R\right]^{2}}{\mathrm{~N}-1}}
$$

$\sigma_{\mathrm{i}} \quad=$ Deviasi standarportofolio

$\mathrm{R}_{\mathrm{i}} \quad=$ Tingkat pengembalian investasi

$\mathrm{R} \quad=$ Rata-rata return reksa dana

$\mathrm{N} \quad=$ Jumlah data

Return risk free

$$
R_{f}=\frac{\Sigma S B I}{\Sigma \text { Periode }}
$$

$\sum \mathrm{SBI}=$ Jumlah suku bunga SBI periode $\mathrm{t}$

$\sum$ Periode $=$ Jumlah periode pengamatan

Setelah mendapatkan hasil perhitungan tersebut, kemudian dapat menghitung kinerja reksa dana menggunakan metode Sharpe dengan rumus sebagai berikut:

$$
S_{i}=\frac{\left[R_{i}-R_{f}\right]}{\sigma_{i}}
$$


Keterangan:

$\mathrm{Si} \quad=$ Nilai Sharpe Ratio

$\mathrm{Ri} \quad=$ Tingkat pengembalian investasi

Rf = Tingkat bebas risiko

$\sigma_{\mathrm{i}} \quad=$ Deviasi standarportofolio

Jenis data yang digunakan dalam penelitian ini adalah data kuantitatif berupa laporan nilai aktiva bersih produk reksa dana.Sedangkan sumber data yang digunakan dalam penelitian ini adalah data sekunder berupa laporan keuangan perusahaan reksa dana yang dipublikasikan oleh Otoritas Jasa Keuangan (OJK).

Populasi dalam penelitian ini adalah seluruh reksa dana saham konvensional dan reksa dana saham syariah yang resmi terdaftar di Otoritas Jasa Keuangan dan aktif selama periode penelitian yaitu 2008 dan 2016. Populasi reksa dana yang masih aktif padatahun 2008 yaitu sebanyak 531 reksa dana konvensional dan 36 reksa dana syariah. Pada tahun 2016 terdapat 1289 reksa dana konvensional dan 136 reksa dana syariah yang aktif. Sedangkan metode penentuan sampel yang digunakan dalam penelitian ini adalah purposive sampling yaitu pemilihan sampel dengan kriteria tertentu terlebih dahulu.Berdasarkan kriteria tersebut, maka dapat diambil 8 sampel reksa dana yang terdiri dari 4 reksa dana saham konvensional dan 4 reksa dana saham syariah pada tahun 2008.Untuk sampel tahun 2016 dapat diambil 38 sampel reksa dana yang terdiri dari 19 reksa dana saham konvensional dan 19 reksa dana saham syariah.

Metode pengumpulan data yang digunakan dalam penelitian ini dilakukan dengan teknik dokumentasi, yang artinya mengumpulkan data dengan mencatat atau copy data yang tercantum di Otoritas Jasa Keuangan (OJK) dan situs resmi 
Bank Indonesia. Metode studi pustaka berupa buku-buku literatur, jurnal-jurnal, penelitian-penelitian terdahulu dan pencarian data pada internet untuk memperoleh landasan teori yang komprehensif mengenai masalah dalam penelitian ini.

Pengujian yang dilakukan adalah pengujian perbedaan kinerja reksa dana konvensional dan reksa dana syariah yang diukur dengan metode Sharpe. Uji beda untuk jenis penelitian yang menghasilkan data berskala interval pada umumnya dimaksudkan untuk menguji perbedaan rata-rata hitung diantara kelompokkelompok tertentu yang memiliki persyaratan tertentu yang diteliti. Jika kelompok sampel yang ingin diuji perbedaan rata-rata hitung hanya terdiri dari dua kelompok, teknik statistik yang digunakan pada umumnya adalah teknik $\mathrm{t}$-test (Nurgiyantoro, 2004). Untuk menguji dua kelompok yang subjeknya berbeda, namun dikenakan perlakuan yang sama, maka teknik analisis yang dapat digunakan adalah $\mathrm{t}$-test untuk sampel bebas (independent sample). Sebelum melakukan t-test, dilakukan 2 uji terlebih dahulu, yaitu uji normalitas dan uji homogenitas.

\section{HASIL DAN PEMBAHASAN}

Metode Sharpe atau Sharpe Ratio merupakan metode yang digunakan untuk mengukur kinerja reksa dana yang didasarkan pada seberapa besar penambahan hasil investasi yang diperoleh untuk setiap unit risiko yang diambil. Return risk free merupakan investasi dengan bebas risiko yang diasumsikan dengan tingkat rata-rata suku bunga Sertifikat Bank Indonesia (SBI) pada periode tertentu. Return 
risk free dapat diketahui dengan cara jumlah suku bunga pada suatu periode dibagi dengan periode pengamatan. Rata-rata return risk free pada tahun 2008 dan tahun 2016 dapat dilihat pada tabel 1.

Tabel 1.

Rata-rata Return, Deviasi Standar atau Risiko dan Return Risk Free

\begin{tabular}{lcccc}
\hline & \multicolumn{2}{c}{2008} & \multicolumn{2}{c}{2016} \\
\cline { 2 - 5 } & Konvensional & Syariah & Konvensional & Syariah \\
\hline Return & $-0,1559$ & $-0,2631$ & 0,1103 & 0,2190 \\
Deviasi Standar atau Risiko & 0,1383 & 0,1732 & 0,0950 & 0,1062 \\
Return Risk Free & & 0,0910 & 0,0645 \\
\hline Sumber: Data diolah, 2018 & \multicolumn{3}{c}{}
\end{tabular}

Setelah mendapatkan hasil perhitungan diatas, dapat dihitung metode Sharpe untuk reksa dana konvensional dan syariah pada tahun 2008 dan 2016. Hasil perhitungan rata-rata metode Sharpe dapat dilihat pada tabel 2.

Tabel 2.

Hasil Perhitungan Metode Sharpe

\begin{tabular}{lcccc}
\hline \multirow{2}{*}{ Bulan } & \multicolumn{2}{c}{2008} & \multicolumn{2}{c}{2016} \\
\cline { 2 - 5 } & Konvensional & Syariah & Konvensional & Syariah \\
\hline Januari & $-3,3079$ & $-3,3333$ & $-14,2297$ & 2,0906 \\
Februari & 0,2849 & 1,3207 & 3,9346 & 4,0245 \\
Maret & $-2,7810$ & $-2,6623$ & 3,7453 & 3,8567 \\
April & $-3,1041$ & $-3,4262$ & $-7,2093$ & 3,3989 \\
Mei & 1,7896 & 1,7842 & $-16,3253$ & $-8,1421$ \\
Juni & $-3,9566$ & $-5,2563$ & 4,1400 & 4,2352 \\
Juli & $-3,4439$ & $-2,7794$ & 4,0059 & 4,1749 \\
Agustus & $-3,5376$ & $-2,8672$ & 3,7926 & 2,6060 \\
September & $-2,7067$ & $-2,5707$ & $-5,1641$ & $-5,4166$ \\
Oktober & $-2,5132$ & $-2,4865$ & $-7,6228$ & 3,5465 \\
November & $-0,4707$ & 0,3128 & $-4,6924$ & $-4,7043$ \\
Desember & 1,6714 & 0,5767 & 3,6834 & $-8,7632$ \\
Rata-Rata & $-1,8397$ & $-1,7823$ & $-2,6618$ & 0,0756 \\
\hline Sumber: Data diolah, 2018 & & &
\end{tabular}

Hasil perhitungan Sharpe index tidak hanya menampilkan hasil perhitungan rata-rata kedua jenis reksa dana tetapi juga menampilkan hasil perhitungan metode Sharpe per-sampel reksa dana. Besar Sharpe ratio menunjukkan bahwa dari $1 \%$ risiko total yang ditanggung suatu reksa dana, maka investor memperoleh excess return atas risk free sebesar hasil sharpe index.Contohnya seperti pada 
bulan februari tahun 2016, reksa dana konvensional menunjukkan rasio sebesar 3,9346 dan syariah menunjukkan rasio 4,0245. Hal ini artinya setiap $1 \%$ risiko yang ditanggung, maka reksa dana konvensional memperoleh excess return sebesar 3,93\% dan reksa dana syaria 4,02\%.

Statistik deskriptif adalah statistik yang digunakan untuk menganalisis data dengan cara mendeskripsikan atau menggambarkan data yang telah terkumpul (Anshori dan Iswati, 2009:116). Pada tabel 2, terdapat beberapa bulan yang menghasilkan rasio Sharpe positif. Pada bulan tersebut kinerja reksa dana konvensional relatif lebih baik jika dibandingkan dengan bulan lainnya. Bulan yang menghasilkan rasio positif tersebut tidak dapat menaikkan nilai rata-rata yang dihasilkan reksa dana konvensional tahun 2008. Rata-rata rasio Sharpe reksa dana konvensional pada tahun 2008 memiliki rata-rata rasio sebesar $-1,8397$. Rasio ini menunjukkan hasil yang negatif dikarenakan rata-rata pergerakan hasil imbal atau return reksa dana konvensional pada tahun 2008 lebih kecil jika dibandingkan dengan tingkat risk free. Pada reksa dana syariah, terdapat juga beberapa bulan yang menunjukkan rasio positif. Rasio positif tersebut juga tidak dapat menaikkan tingkat rata-rata rasio Sharpe yang dihasilkan reksa dana syariah. Hasil rata-rata reksa dana syariah pada tahun 2008 menunjukkan hasil yang negatif yaitu sebesar-1,7823. Rasio ini juga menunjukkan bahwa rata-rata tingkat return reksa dana syariah lebih kecil jika dibandingkan dengan tingkat risk free.

Pada tahun 2016, reksa dana konvensional menghasilkan lebih banyak menghasilkan bulan-bulan yang negatif. Hal ini menyebabkan rata-rata rasio 
Sharpe reksa dana konvensional pada tahun 2016 menunjukkan hasil yang negatif yaitu sebesar -2,6618. Rasio ini menunjukkan bahwa rata-rata tingkat return reksa dana konvensional lebih kecil jika dibandingkan dengan risk free rate.Pada reksa dana syariah, rasio positif lebih banyak dibandingkan rasio yang negatif. Hal ini menunjukkan bahwa reksa dana syariah menghasilkan rasio yang positif yaitu sebesar 0,0756, artinya tingkat return reksa dana syariah lebih besar jika dibandingkan dengan risk free rate.

Pengujian Independent T-test dilakukan pada kinerja reksa dana konvensional dan syariah yang dihitung menggunakan metode Sharpe, yaitu metode yang digunakan untuk menguji kinerja reksa dana selama periode krisis yaitu tahun 2008 dan periode non krisis yaitu tahun 2016. Hasil pengujian ini didapat setelah dilakukan pengolahan data dengan menggunakan aplikasi $I B M$ SPSS Statistic 20. Sebelum dilakukan uji Independent T-test, dilakukan uji normalitas dan uji homogenitas terlebih dahulu. Hasil uji normalitas untuk metode Sharpepada tahun 2008 dan tahun 2016 dapat dilihat pada tabel 3.

Tabel 3.

Hasil Uji Normalitas Kinerja Reksa Dana Konvensional dan Syariah Tahun 2008 dan Tahun 2016

\begin{tabular}{cccccccc}
\hline & \multicolumn{3}{c}{2008} & & \multicolumn{3}{c}{2016} \\
\cline { 2 - 8 } Sharpe & Reksa dana & Statistik & df & Sig. & Statistik & df & Sig. \\
& Syariah & 0,948 & 12 & 0,614 & 0,966 & 12 & 0,864 \\
& Konvensional & 0,908 & 12 & 0,204 & 0,911 & 12 & 0,217 \\
\hline
\end{tabular}

Sumber: Data diolah, 2018

Berdasarkan tabel 3., pengujian normalitas dengan metode ShapiroWilkmenunjukkan bahwa kedua rasio Sharpe reksa dana pada tahun 2008 menunjukkan signifikansi $>0,05$, yang artinya seluruh data memenuhi syarat yaitu terdistribusi normal. Pada tahun 2016 menunjukkan signifikansi $>0,05$, 
yang artinya seluruh data memenuhi syarat yaitu terdistribusi normal. Setelah melakukan uji normalitas, dapat dilanjutkan dengan uji homogenitas. Hasil uji homogenitas metode Sharpepada tahun 2008 dan tahun 2016 dapat dilihat pada tabel 4 .

Tabel 4.

Hasil Uji Homogenitas Kinerja Reksa Dana Konvensional dan Syariah Tahun 2008 dan Tahun 2016

\begin{tabular}{ccccc}
\hline \multirow{2}{*}{2008} & Levene Statistic & $\mathrm{df1}$ & $\mathrm{df2}$ & Sig. \\
\cline { 2 - 5 } & 0,007 & 1 & 22 & 0,935 \\
\hline \multirow{2}{*}{2016} & Levene Statistic & $\mathrm{df} 1$ & $\mathrm{df2}$ & Sig. \\
\cline { 2 - 5 } & 3,467 & 1 & 22 & 0,076 \\
\hline
\end{tabular}

Sumber: Data diolah, 2018

Hasil uji pada tabel 4. menunjukkan bahwa rasio Sharpe reksa dana konvensional dan syariah pada tahun 2008 memiliki nilai signifikansi $>0,05$, artinya rasio Sharpe reksa dana konvensional dan syariah pada tahun 2008 mempunyai varian yang sama atau homogen. Pada tahun 2016 memiliki nilai signifikansi $>0,05$, artinya rasio Sharpe reksa dana konvensional dan syariah pada tahun 2016 mempunyai varian yang sama atau homogen. Setelah melakukan uji normalitas dan homogenitas, dapat dilanjutkan dengan uji independent t-test. Hasil uji independent t-test metode Sharpe pada tahun 2008 dan tahun 2016 dapat dilihat pada tabel 5 .

Tabel 5.

Hasil UjiIndependent t-test Kinerja Reksa Dana Konvensional dan Syariah Tahun 2008 dan Tahun 2016

\begin{tabular}{|c|c|c|c|c|c|c|c|}
\hline & & \multicolumn{6}{|c|}{ t-test for Equality of Means } \\
\hline & & \multicolumn{3}{|c|}{2008} & \multicolumn{3}{|c|}{2016} \\
\hline & & $\mathrm{t}$ & Df & Sig. (2-tailed) & $\mathrm{t}$ & $\mathrm{df}$ & Sig. (2-tailed) \\
\hline Sharpe & $\begin{array}{c}\text { Equal variances } \\
\text { assumed }\end{array}$ & $-0,031$ & 22 & 0,975 & 2,973 & 22 & 0,007 \\
\hline
\end{tabular}


Berdasarkan hasil uji pada tabel diatas, diperoleh Sig. 0,975. Karena Sig. 0,975 >0,05 dengan demikian H1 ditolak. Hal ini artinya tidak terdapat perbedaan signifikan antara kinerja reksa dana saham syariah dan reksa dana saham konvensional pada tahun 2008. Hasil dari pengujian Independent T-testreturn reksa dana saham konvensional dan reksa dana saham syariah pada tahun 2016 berdasarkan hasil uji pada tabel diatas, diperoleh Sig. sebesar 0,007. Karena Sig. $0,007<0,05$ dengan demikian $\mathrm{H} 2$ diterima. Hal ini artinya terdapat perbedaan yang signifikan antara kinerja reksa dana saham syariah dan reksa dana saham konvensional pada tahun 2016.

Berdasarkan hasil dari uji Independent T-test kinerja reksa dana konvensional dan syariah pada periode krisis yang dihitung menggunakan metode Sharpe, diketahui bahwa pada periode krisis tidak ada perbedaan kinerja antara reksa dana syariah dan konvensional. Hasil uji Independent T-test ini juga didukung hasil perhitungan metode Sharpe yang menunjukkan bahwa rasio Sharpe reksa dana syariah dan konvensional pada periode krisis yaitu tahun 2008 sama-sama memiliki rasio yang negatif.

Hasil penelitian ini sejalan dengan penelitian Ridho (2008) tentang perbandingan kinerja reksa dana syariah dan konvensional dengan indeks Sharpe, Treynor dan Jensen yang juga menghasilkan kesimpulan yang sama, yaitu secara statistik tidak dapat perbedaan kinerja reksa dana syariah dan reksa dana konvensional. Kondisi perekonomian pada saat periode krisis merupakan salah satu penyebab tidak terdapatnya perbedaan antara kinerja reksa dana syariah dan reksa dana konvensional. Hal ini mengakibatkan kinerja saham atau perusahaan 
tidak melakukan performa yang baik juga. Selain hal tersebut, hasil ini juga merupakan bukti bahwa perkembangan ekonomi syariah di Indonesia khususnya di pasar modal memiliki kinerja yang tidak kalah baik dibandingkan dengan konvensional.

Dalam hal religius juga, syariah lebih dapat dipertanggungjawabkan karena melaksanakan serangkaian proses yang sesuai dengan prinsip-prinsip syariah. Dalam hasil penelitian yang dilakukan, industri atau perusahaan yang hanya bisa dipilih oleh reksa dana syariah karena sesuai dengan prinsip syariah tidak menunjukkan performa yang lebih baik jika dibandingkan dengan reksa dana konvensional pada periode krisis. Meskipun industri atau perusahaan yang dipilih oleh reksa dana syariah terbatas karena harus sesuai dengan prinsip syariah, kinerja reksa dana syariah dapat mengimbangi kinerja reksa dana konvensional pada periode krisis.

Berdasarkan hasil uji Independent T-test kinerja reksa dana konvensional dan syariah pada periode non krisis yang dihitung menggunakan metode Sharpe, diketahui bahwa pada periode tersebut terdapat perbedaan kinerja antara reksa dana syariah dan konvensional. Penelitian yang dilakukan oleh Putra dan Fauzie (2014) yang menyatakan bahwa terdapat perbedaan kinerja antara reksa dana syariah dan reksa dana konvensional.

Hasil uji Independent T-test ini juga didukung dengan hasil perhitungan metode Sharpe yang menunjukkan bahwa rasio Sharpe reksa dana syariah memiliki rasio yang positif dan reksa dana konvensional memiliki rasio yang negatif. Rasio Sharpe yang dihasilkan reksa dana syariah berasal dari return dan 
risiko. Dilihat dari return dan risiko, reksa dana syariah memiliki return yang lebih baik dibandingkan reksa dana konvensional. Return reksa dana syariah yang lebih tinggi ini juga mengakibatkan naiknya risiko reksa dana syariah. Ini sesuai dengan konsep "High Risk High Return”.

Selain hal tersebut, reksa dana syariah juga sudah menerapkan teori investasi secara maksimal, yaitu dengan meningkatkan return dan meminimalkan risiko. Hal ini dapat dilihat dari rata-rata return reksa dana syariah lebih tinggi dan risiko hanya berbeda sedikit dari reksa dana konvensional. Adanya perbedaan ini disebabkan karena prinsip pokok reksa dana syariah dan reksa dana konvensional dalam mengelola portofolio investasinya sehingga memiliki hasil yang berbeda. Walaupun dalam mengelola portofolio investasi berbeda dan pilihan portofolio yang terbatas, kinerja reksa dana syariah dapat mengungguli reksa dana konvensional pada periode non krisis. Ini menunjukkan bahwa perkembangan syariah sangat pesat, khususnya reksa dana syariah karena reksa dana syariah yang umurnya lebih baru dibandingkan dengan reksa dana konvensional yang sudah lebih lama.

Hasil dari penelitian ini menunjukkan bahwa kinerja reksa dana syariah lebih baik dibandingkan reksa dana konvensional pada periode non krisis. Pada periode krisis, kinerja reksa dana syariah tidak lebih baik dari reksa dana konvensional. Hal ini disebabkan karena sampel reksa dana yang terdapat pada periode krisis hanya sedikit. Hasil tersebut juga didukung oleh penelitian Djaddang \& Susilawati (2016) menunjukkan bahwa tidak dapat perbedaan yang signifikan antara reksa dana syariah dan konvensional. Penelitian ini juga 
membuktikan bahwa reksa dana syariah memiliki kinerja yang tidak buruk dan mampu menyaingi reksa dana konvensional pada periode krisis dan non krisis. Reksa dana syariah juga dapat membuktikan bahwa dengan pemilihan saham atau portofolio yang tepat walaupun memiliki batasan pemilihan saham yang sesuai dengan syariatislam, reksa dana syariah dapat mengungguli reksa dana konvensional. Reksa dana syariah tidak memiliki performa yang lebih buruk dibandingan dengan konvensional, artinya batasan syariat islam tidak membatasi kinerja reksa dana.

\section{SIMPULAN}

Berdasarkan pembahasan hasil penelitian, dapat ditarik kesimpulan yaitu dalam periode krisis, kinerja reksa dana syariah menunjukkan bahwa reksa dana syariah tidak memiliki kinerja yang lebih baik dibandingkan dengan reksa dana konvensional. Hal ini ditunjukkan dengan hasil Independent t-test menyatakan tidak terdapat perbedaan.Dalam periode non krisis, kinerja reksa dana syariah memiliki kinerja yang lebih baik dibandingkan reksa dana konvensional. Hal ini ditunjukkan dengan hasil Independent t-test juga menunjukkan bahwa terdapat perbedaan antara reksa dana syariah dan reksa dana konvensional.Sedangkan saran yang dapat diberikan yaitu investor yang akan berinvestasi pada reksa dana, sebaiknya melihat terlebih dahulu risiko dan tingkat pengembalian masa lalu reksa dana tersebut. Reksa dana syariah bisa menjadi pertimbangan bagi para investor khususnya investor Indonesia, dimana mayoritas investor Indonesia adalah beragama Islam. Reksa dana syariah memberikan kenyamanan pada investor 
karena manajer investasi menginvestasikan dana investor tersebut pada produkproduk yang sesuai ketentuan Islam.

Implikasi hasil dalam penelitian ini membuktikan bahwa kinerja reksa dana syariah dapat mengungguli kinerja reksa dana konvensional pada periode krisis dan non krisis. Reksa dana syariah juga membuktikan bahwa pemilihan saham atau portofolio yang tepat walaupun memiliki batasan dalam pemilihannya menghasilkan kinerja yang lebih baik dibandingkan dengan reksa dana konvensional yang bebas untuk memilih saham atau portofolionya.

\section{REFERENSI}

Buana, B. P. (2016). Perbandingan Kinerja Reksa Dana Syariah Saham, Reksa Dana Syariah Pendapatan Tetap, dan Reksa Dana Syariah Campuran dengan Metode Sharpe (periode 2012-2014).

Djaddang, S., \& Susilawati. (2016). Kinerja reksa dana syariah dan konvensional: aplikasi model jensen. Jurnal Organisasi Dan Manajemen, 12.

Hayat, R., \& Kraeussl, R. (2011). Risk and return characteristics of Islamic equity funds. Emerging Markets Review, 12(2), 189-203. https://doi.org/10.1016/j.ememar.2011.02.002

Herlianto, D. (2010). Seluk Beluk Investasi di Pasar Modal di Indonesia (1st ed.). Yogyakarta: BPFE Yogyakarta.

Hermawan, D., \& Wiagustini, N. L. P. (2016). Pengaruh Inflasi, Suku Bunga, Ukuran Reksa Dana, dan Umur Reksa Dana terhadap Kinerja Reksa Dana. E-Jurnal Manajemen Unud, 5(5), 957-962. Retrieved from https://ojs.unud.ac.id/index.php/Manajemen/article/view/20110/13606

Hussein, K. A. (2005). Islamic Investment: Evidence From Dow Jones and FTSE indices. 6th International Conference on Islamic Banking and Finance, November 21-24, 1-14.

IAEI. (2013). Investasi Syariah menguntungkan dunia dan akhirat. Ikatan Ahli Ekonomi Indonesia. Retrieved from www.iaei-pusat.org

Lawn, N. D., Westmoreland, B. F., Kiely, M. J., Lennon, V. A., \& Vernino, S. 
(2003). Clinical, Magnetic Resonance Imaging, and Electroencephalographic Findings in Paraneoplastic Limbic Encephalitis. In Mayo Clinic Proceedings (2nd ed., Vol. 78). https://doi.org/10.4065/78.11.1363

Lestari, W. R. (2016). Kinerja Reksadana Saham Syariah Dan Reksadana Saham Konvensional. Jurnal Manajemen Magister Darmajaya, 1(01), 116-128.

Mansor, F., \& Ishaq Bhatti, M. (2011). Risk and Return Analysis on Performance of the Islamic mutual funds: Evidence from Malaysia*. Global Economy and Finance Journal, 4(1), 19-31.

Margaretha, F., \& Lyberisa. (2014). Perbedaan Kinerja Reksa Dana Konvensional dan Syariah.

Merdad, H., Hassan, M. K., \& Alhenawi, Y. (2010). Funds Performance in Saudi Arabia: A Case Study. Journal of King Abdulaziz University: Islamic Economics, 23(2), 157-193.

Nurgiyantoro, B. (2004). Statistik Terapan Untuk Penelitian Ilmu-Ilmu Sosial.

Otoritas Jasa Keuangan. (2016). Pasar Modal - Pasar Modal Syariah. In Ojk. Retrieved from https://www.ojk.go.id/id/kanal/pasarmodal/Pages/Syariah.aspx

Putra, J., \& Fauzie, S. (2014). Analisis Perbandingan Kinerja Reksa Dana Konvensional Dengan Reksa Dana Syariah di Indonesia. Jurnal Ekonomi Dan Keuangan, 2(5), 282-295. Retrieved from https://jurnal.usu.ac.id/index.php/edk/article/view/11686/5044

Sharpe, W. F. (2015). Investasi Jilid 1 (ed. 6). Jakarta: Indeks.

Syafrida, I., Aminah, I., \& Waluyo, B. (2014). Pada Pasar Modal Di Indonesia. (April), 195-206.

Syahna, M. (2009). Analisis Komparasi Kinerja Reksadana Syariah Dan Konvensional ( Kategori Saham , Campuran dan Pendapatan Tetap) di Indonesia. Retrieved from http://lib.ui.ac.id/file?file=digital/123229-6096Komparasi kinerja-HA.pdf

Syariah, R., \& Indonesia, D. I. (n.d.). Membangun Brand Image Reksadana Syariah Di Indonesia Oleh: Taufiqur Rahman. 35-52.

Tandelilin, E. M. B. . (2001). Analisis Investasi dan Manajemen Portofolio (1st ed.). Yogyakarta: BPFE Yogyakarta. 